\title{
MAIN STAGES OF DEVELOPMENT AND MODERN-STATE-OF-ART OF PHOTODYNAMIC THERAPY IN RUSSIA
}

\author{
E.Ph. Stranadko \\ Dr. Sci. (Med.), Prof., Head of the department \\ Department of Laser Oncology and Photodynamic \\ Therapy \\ State Scientific Center for Laser Medicine of the Ministry \\ of Health of Russia \\ 40 Studencheskaya St., Moscow, 121165, Russia \\ tel.: +7 (917) 533-26-88 \\ e-mail: seph04@yandex.ru \\ ORCID 0000-0002-1589-7661
}

\author{
T.I. Malova \\ Director general \\ LLC "Veta-Grand" \\ 38 Malaya Gruzinskaya St., korp. 1, Moscow, 123557, \\ Russia \\ tel.: +7 (917) 533-26-88 \\ e-mail: seph04@yandex.ru \\ ORCID 0000-0003-0689-3754
}

The article discusses main stages of 25-year development of photodynamic therapy (PDT) in Russia. It underlines that the initiator of PDT development in Russia was Academician Prof. Oleg Skobelkin, director of the Clinical and Research Center for Laser Medicine, Healthcare Ministry of Russian Federation. He united efforts of some institutions of chemical and physical profile so as to develop home-made photosensitizers (PS) and to develop laser devices for PDT application. In 1990 a group of scientists headed by prof Mironov from Moscow State University of Fine Chemical Technologies named after Lomonosov developed the first Russian PS out of the group of hematoporphyrine derivatives - Photohem. In the State Research and Clinical Center for Laser Medicine Photohem preclinical trials had been conducted, the material and technical basis for clinical trials had been prepared, a permission from Pharmacological Committee of Russia for clinical trials had been received. After that in February, 1992, PDT was used for treating patients with recurrent and metastatic tumors which were absolutely non-perspective for traditional curative techniques.

In the last six years a number of PS of the second generation (Photosense, Alasense, Photoditazine, Radachlorine, etc.) have been developed in Russia; Russian laser devices for PDT and fluorescent diagnostics have been worked out too. PDT clinical application has acquired a wide-scale character. PDT is used in tumors of external and visceral locations, in early and extended pathology stages (palliative) as a component of combined and complex cancer treatment. Currently, PDT is widely used in a number of non-tumoral pathologies in ophthalmology, gynecology, purulent surgery, dermatology, etc. PDT is used not only in institutes and research centers but also in practical medicine. The PDT course is included into educational programs for physicians' post-diploma education. Russian scientists take an active part in international scientific meetings including those of World Photodynamic Association as well as in international research projects.

Key words: photodynamic therapy, stages of development it in Russia, modern-state-of-art.

\section{ОСНОВНІ ЕТАПИ РОЗВИТКУ ТА СУЧАСНИЙ СТАН ФОТОДИНАМІЧНОї ТЕРАПІї В РОСІї}

\author{
G.Ф. Странадко ${ }^{1}$, Т.I. Малова ${ }^{2}$ \\ ${ }^{1}$ ФДБЗ «Державний науковий центр лазерної медицини \\ Федерального медико-біологічного агентства Росї », м. Москва, Росія; \\ ${ }^{2}$ ТОВ «ВЕТА-ГРАНД», м. Москва, Росія
}

В статті представлені основні етапи 25-річного розвитку фотодинамічної терапії (ФДТ) в Росії. Відзначено, що ініціатором розробки методу ФДТ був директор ГНЦ лазерної медицини, членкореспондент РАМН, професор О.К. Скобєлкін. Він об'єднав зусилля низки інститутів хімічного та фізичного профілю для створення вітчизняних фотосенсибілізаторів $(\Phi C)$ та розробки лазерних апаратів для ФДТ. У 1990 році в Московському інституті тонкої хімічної технології ім. М.В. Ломоносова під керівництвом професора А.Ф. Міронова був розроблений перший вітчизняний фотосенсибілізатор із групи гематопорфірину - Фотогем. У ГНЦ лазерної медицини були проведені прециклічні випробування Фотогема, підготовлена матеріально-технічна база для проведення клінічної ФдТ, отримано дозволи Фармакологічного комітету на клінічні випробування і з лютого 1992 року ми почали застосовувати ФДТ у пацієнтів з рецидивними та метастатичними пухлинами, абсолютно безперспективними для традиційних методів лікування.

В наступні 6 років створено цілий ряд фотосенсибілізаторів другого покоління (фотосенс, аласценс, фотодитазин, радахлорін та ін.) та розроблена вітчизняна лазерна техніка для ФДТ та флюоресцентної 
діагностики. Клінічне застосування Фдт придбало широкомасштабний характер. В даний час ФдТ застосовується при пухлинах зовнішніх та віцеральних локалізацій ракових, ранніх і поширених стадій процесу (паліативна ендоскопічна ФДТ), як компонент комбінованого та комплексного лікування раку різноманітних локалізацій. ФдТ в Росії знайшла широке застосування в цілій низці непухлинниих захворювань: у офтальмології, в гнійній хірургії, в оториноларингології, гінекології, дерматології та ін. ФДТ застосовується не тільки в інститутах і наукових центрах, але і в практичних лікувальних установах. В інститутах викладається предмет ФДТ на курсах підвищення кваліфікації лікарів. Російські вчені беруть активну участь у міжнародному співробітництві та виступають з науковими доповідями на конгресах Всесвітньої фотодинамічної асоціації та конференціях з лазерної медицини як в Росії, так і за кордоном.

Ключові слова: фотодинамична терапія, етапи розвитку, сучасний стан.

\title{
ОСНОВНЫЕ ЭТАПЫ РАЗВИТИЯ И СОВРЕМЕННОЕ СОСТОЯНИЕ ФОТОДИНАМИЧЕСКОЙ ТЕРАПИИ В РОССИИ
}

\author{
Е.Ф. Странадко ${ }^{1}$, Т.И. Малова ${ }^{2}$ \\ ${ }^{1}$ ФББУ «Государственный научный центр лазерной медицины \\ Федерального медико-биологического агентства России», г. Москва, Россия; \\ ${ }^{2} \mathrm{OОО}$ «ВЕТА-ГРАНД», г. Москва, Россия
}

В статье приведены основные этапы 25-летнего развития фотодинамической терапии (ФДТ) в России. Отмечено, что инициатором разработки метода ФдТ был директор ГНЦ лазерной медицины, членкорреспондент РАМН, профессор О.К. Скобелкин. Он объединил усилия ряда институтов химического и физического профиля для создания отечественных фотосенсибилизаторов (ФС) и разработки лазерных аппаратов для ФДТ. В 1990 году в Московском институте тонкой химической технологии им. М.В. Ломоносова под руководством профессора А.Ф. Миронова разработан первый отечественный фотосенсибилизатор из группы производных гематопорфирина - Фотогем. В ГНЦ лазерной медицины были проведены предклинические испытания Фотогема, подготовлена материально-техническая база для проведения клинической Фдт, получено разрешение Фармакологического комитета на клинические испытания и с февраля 1992 года мы начали применять ФдТ у больных с рецидивными и метастатическими опухолями, абсолютно бесперспективных для традиционных методов лечения.

В последующие 6 лет создан целый ряд фотосенсибилизаторов второго поколения (фотосенс, аласенс, фотодитазин, радахлорин и другие) и разработана отечественная лазерная аппаратура для ФДТ и флюоресцентной диагностики. Клиническое применение ФдТ приобрело широкомасштабный характер. В настоящее время ФДТ применяется при опухолях наружных и висцеральных локализациях рака, ранних и распространенных стадиях процесса (паллиативная эндоскопическая ФдТ), как компонент комбинированного и комплексного лечения рака различных локализаций. ФДТ в России нашла широкое применение при целом ряде неопухолевых заболеваний: в офтальмологии, в гнойной хирургии, в оториноларингологии, гинекологии, дерматологии и др. ФДТ применяется не только в институтах и научных центрах, но и в практических лечебных учреждениях. В институтах ведется преподавание предмета ФДТ на курсах повышения квалификации врачей. Российские ученые принимают активное участие в международном сотрудничестве и выступают с научными докладами на конгрессах Всемирной фотодинамической ассоциации и конференциях по лазерной медицине как в России, так и за рубежом.

Ключевые слова: фотодинамическая терапия, этапы развития, современное состояние.

Twenty five years of development and practical application of photodynamic therapy (PDT) is marked in Russia. Among the European countries, Russia was one of the pioneers of development of clinical PDT. The initiator of the development of the PDT was the head of the Institute, the corresponding member of the Russian Academy of Medical Sciences (RAMS), Professor O.K.Skobelkin. He organized a group of enterprising researchers to create and develop domestic photosensitizers (PS) and develop laser devices for PDT [1-4]. He combined efforts of some institutions of chemical and physical profile. The work was carried out simultaneously in a number of directions. As a result of the experimental studies conducted in the State Scientific Center of Laser Medicine (SSCLM) of Ministry of Health of the Russian Federation, at a stage of preclinical study of general-toxic and specific types of action of hematoporphyrine derivative, average lethal doses of hematoporphyrine derivative had been determined, the acute dark and light toxicity had been studied, boundaries of therapeutic dose had been determined, depending on various light modes, regularities of a photosensitizing tanatogenesis had been described in the first, which played an important role in the subsequent in development of morphological criteria for the efficiency of PDT in the clinical trials of various PS.

In numerous experiments features of pharmacokinetics at intravenous and intra-abdominal introduction methods of a PS had been studied, indisputable advantages of derivative hematoporphyrine for diagnostics and treatment of malignant tumors before to 
other dyes had been fitted. In experiments on rats the high efficiency of PDT at intravenous administration of a PS was proved [5-9]. Special interest in porphyrines was caused by a unique combination of spectral energy and chemical characteristics, which provide not only intensive absorption of light radiation in the visible range of light, but also its transformation with high intensity in energy of highly reactive intermediates, capable to cause deep damages of various components of biological structures, first of all malignant tumors. However, nowhere in the interested research establishments institutes of the country, the clinical trials of PDT with foreign and domestic PS has not conducted yet. In 80th years of the XX century in the Moscow Institute of Fine Chemical Technology named after M.V.Lomonosov under the leadership of the professor A.F.Mironov the extensive studies on the screening of various dyes for detection of photosensitizing properties and chemical modification of hematoporphyrine were deployed.These efforts quickly proved to be very successful and in 1990 it resulted in receiving the first domestic PS from the group of hematoporphyrine derivatives, which was named Photohem [10-14].

Despite of the appearance of the dosage form of Photohem, it wasn't found in clinical conditions of its photosensitizing properties, effective therapeutic dose, the breadth of therapeutic action, the optimal parameters of laser radiation, the phototoxicity and possible other adverse reactions and complications.

Based on previously conducted in SSCLM pre-clinical studies of specific photosensitizing (light toxicity) and general toxic (dark toxicity) of Photohem action, pre-clinical trials of PDT of transplantable tumor in experimental animals [5-7], documents were prepared, permission to clinical trials of Pharmacological Committee of the USSR were obtained, and in February, 1992 was used for clinical trials of the PDT with Photohem [13,15-23].

In SSCLM the material and technical base for conducting clinical PDT had been prepared by that time: the room was equipped and purchased the dye laser "Innova-200", pumped by argon laser, from American firm "Coherent" (wavelength of the light radiation was $630 \mathrm{~nm}$, output power of radiation in continuous mode $5 \mathrm{~W})$. Concurrently domestic lasers and non-laser light sources for PDT with Photohem were developed in the SSCLM together with technical collaborators according to the Programme of development and implementation of the method of PDT in Russia [1,2,4,24-26].

The drug Photohem is the lyophilized sodium salt of hematoporphyrine derivative, obtained from the defibrinated blood and exhibit powerful properties of sensitization tissues to the light radiation of visible range of the spectrum, low toxicity, moderately expressed immunostimulating action. The clinical trials had shown that Photohem is the effective tumor remedy, possessing big and therapeutic breadth, and that it was similar to known foreign PS from group of hematoporphyrine derivatives.
PDT was used for most accessible tumors of exterior locations: skin cancer, intracutaneous metastases of breast cancer and melanoma, cancers of the tongue and oral mucosa. The first patients were with recurrent and metastatic tumors, absolutely unpromising for the traditional methods of treatment (surgery, radiotherapy, combined and even complex). PDT was performed in a hospital, in a specially equipped darkened wards, after tests on a medicinal allergy to Photohem and sensitivity to laser light.

It should be noted that initial clinical trials carried out quite intensely. During the first year 33 patients with various malignant tumors had been treated by the method of PDT. Despite the severe contingent of the patients subjected to PDT, 30 patients of them (91\%) were obtained positive effect, including 16 patients $(48,5 \%)$ which were complete resorption of tumors. The results of the first year of clinical trials of PDT with Photohem were reported at the 1st European Congress from 1 to 3 September, 1993, in Budapest (Hungary) [13]. Based on the results of the first courses of PDT with full or pronounced (more than 50\%) resorption of superficial tumors in the absence of complications, we have started to apply interstitial PDT of breast cancer since April, 1992, and in Seщptember 1, 1992 for the first time in Russia used endoscopic PDT with central cancer of the lower lobe of the left lung with atelectasis [15-19].

In October, 1992 Moscow Oncology Research Institute named after P.A.Herzen joined the program of clinical studies of PDT $[27,28]$. In the next years, the clinical application of PDT in Russia had acquired a wide-scale character. Along with 4 capital institutions (SSCLM of Healthcare Ministry of Russia, Moscow Oncology Research Institute named after P.A.Herzen, Oncological and Research centre of RAMS and faculty surgical clinic of I.M.Sechenov Moscow Medical Academy), PDT began to be used in Medical Radiological Research Center of RAMS (Obninsk), the number of regional centers of laser medicine, at the clinical basis of departments of medical universities and in practical medical institutions [11,27,29-33].

In 1994 the PS of second generation Photosens - sulphurized phthalocyanine aluminum (wavelength of the exciting light $675 \mathrm{~nm}$ ) in SSC "NIOPIK" had been synthesized and submitted for clinical trials. First we reported clinical application of PDT for cancer treatment with various localizations at the Joint Conference of the European Laser Association and International Society of Biomedical Optics, in Lille (France) from 9 to 10 September, 1994 [21]. Subsequently in SSC "NIOPIK" the foreign analog of 5-aminolevulinic acid (ALA) Alasens had been developed and of new PS had been continued development. In future clinical trials of PDT with Photosense within the cooperated clinical trials had been developed and in other Moscow research institutes and in practical medical institutions $[4,11,22,23,31,34,35]$. 
Our experience of the first 5 years of clinical application of PDT was reflected in the articles in the first issue of the journal "Laser medicine" [36]. By that time PDT was conducted with 288 patients with 1210 foci of tumors of various localizations.

In 1996-1998 in the Institute of Biomedical Chemistry RAMS named after V.N.Orehovich professor G.V.Ponomarev and his students created a number of the second generation of PS, which were derivatives of chlorin E6 (Photoditazine, Radachlorin, etc.) with a wavelength of $662 \mathrm{~nm}$ excitation light, and already in 1998 in the SSCLM had been started clinical trials of Photoditazin [32,37-40]. It was conducted on 78 tumors of the external and internal locations in 72 patients. Photoditazin has a number of advantages over the first generation PS: a high quantum yield of singlet oxygen, a contrast gradient "tumor/normal tissue" $10 / 1$, rapid clearance (short time of a delay in the normal tissues of the body, less than 2 days) and it completely solves the problem of long-term skin phototoxicity, typical for PS of the first generation. With application of Photoditazin the good results of PDT have been received: 70\% of tumors have subjected complete resorption. At the present time Photoditazin is the most popular PS for PDT of cancer and many non-neoplastic diseases [35,38,40-45] in Russia. All of the above mentioned PS of the Russian production was registered in the Healthcare Ministry of Russia and have the permission of Pharmacological Committee to application in clinical practice.

The domestic laser equipments for fluorescent diagnostics and PDT were created [1,4,25,35]. In the leading scientific centers of Russia, specialized in laser medicine, oncology and medical physics, experimental and clinical studies of new PS, the methods of fluorescence diagnostics and clinical protocols for PDT of tumors of the main localizations are developed, also of a number of nonneoplastic diseases [46-54]. The offices or the wards of PDT in many territorial centers of laser medicine, regional and city oncology clinics had been organized. For popularization of knowledge of PDT and association of efforts of separate research institutes and centers of laser medicine, we conducted the all-Russian Symposium of photodynamic therapy on the basis of the SSCLM in 1995. In the subsequent, similar symposiums with international participation had carried out every 2 years $(1997,1999,2001)$ with the publication of papers on clinical, experimental and technical research [37,55-57].

The breakout sessions of PDT in the framework of All-Russian Scientific-Practical Conference of Laser Medicine have been conducted since 2003. The works of these conferences are published in the journal "Laser medicine" (in Russian). In SSCLM, Moscow Oncology Research Institute named after P.A.Herzen and some educational institutes began to teach a course of laser and photodynamic therapy. The Russian medical press had been published reports of more than 5000 patients treated with PDT method, which had about 10000 lesions $[12,36,58]$. Most of these patients were treated for skin cancer. On the one hand, it is connected with availability of lesions of cancer skin, a high efficiency of PDT with this localization of cancer and good cosmetic results, and on the other hand, the fact that skin cancer in Russia (even without melanoma are more than 65,000 new cases annually) since 2007 , it occupies the frequency first among all malignant tumors [59,60]. In addition, the widespread introduction of PDT of skin cancer is caused by simplicity of this method in comparison with traditional methods of treatment like surgery and radiation therapy. PDT opens up opportunities of effective treatment for thousands of Russians in the countryside, outside big cities, in which there are surgical and oncological clinics and radiation therapy is conducted.

Another perspective direction of application of this method in Russia is the palliative endoscopic PDT of occlusive malignant tumors of the trachea, large bronchi, esophagus and forestomach, esophageal-intestinal and esophageal-gastric anastomoses [61-65]. One of the last localications of cancer, which is successfully used in PDT is a cancer of the large duodenal papilla and extrahepatic bile ducts $[45,61,62,66,67]$.

A new promising direction of research is studing of the role of PDT in the composition of multicomponent methods of treatment of malignant tumors, which are intensively conducted in the last decade in oncological and X-ray-radiological institutes of Moscow, St. Petersburg, Novosibirsk, Obninsk and other cities of Russia [26,29,33,68-73].

Increasingly popular in Russia becomes antibacterial PDT treatment of long-term non-healing wounds with antibiotic-resistant flora, and trophic ulcers of the vascular etiology, acne vulgaris and other inflammatory diseases of soft tissues [46-50,54]. PDT is used for treating of chronic inflammatory diseases of ENT-organs.

The Russian scientists take an active part in the international forums on laser medicine and PDT: at the Congress of the European Laser Association (from 14 to 16 September, 1995, Barcelona, Spain) Russian scientists had made 15 reports, including 9 clinical of PDT. In Vancouver (Canada) at the 8th World Congress of Photodynamic Association from 5 to 9 June, 2001, the Russian scientists had made 6 reports, at the 9th Congress from 20 to 23 May, 2003 (Miyazaki, Japan) - 14 reports, in Munich (Germany) at the 10th World Congress of Photodynamic Association - 11 reports. At the 15th International Congress of the European Medical Laser Association from 20 to 23 August, 2010 (Helsinki, Finland) Russian scientists had made more than 30 clinical reports of PDT and experimental laser biology and medicine.

Currently the international cooperation in the field of researches on the problem PDT continues to expand $[20,28,74]$. 


\section{References}

1. Armichev AV, Stranadko EPh, Sokolov VV, et al. Experience of using lasers based on copper vapour, gold and dye solutions for photodynamic therapy. In: Mezhd. konf. Novyie napravleniya lazernoy meditsinyi [Intern. Conf. The new directions of laser medicine]. M.; 1996; p. 353. (in Russian)

2. Skobelkin OK, Stranadko EPh, Armichev AV, et al. The possibility of creating complex for diagnostics and photodynamic therapy. In: Mezhdunar. konf. Perspektivnyie napravleniya lazernoy meditsinyi [Intern. Conf. Perspective directions of laser medicine]. Moscow-Odessa; 1992; p. 434-5. (in Russian)

3. Skobelkin OK, Litvin GD, Stranadko EPh, et al. A new stage of development of PDT of malignant tumors in Russia: the photosensitizer chlorin E6 and solid-state laser of red wavelength range. In: Mezhdunar. konf. Novyie dostizheniya lazernoy meditsinyi [Intern. Conf. New achievements in laser medicine]. M.-SPb.; 1993; p. 216-7. (in Russian)

4. Stranadko EPh. Fotodinamicheskaya terapiya. Primenenie nizkointensivnyih lazerov v klinicheskoy praktike [Photodynamic therapy. Application of low-intensity lasers in clinical practice]. Skobelkin OK, editor. Moscow; 1997; p. 173-84. (in Russian)

5. Litvin GD, Petukhov MI, Kolobanova AS, Stranadko EPh, Andreeva KP. Research of dark toxicity of Photohem . In: Mezhdunar.konf. Perspektivnyie napravleniya lazernoy meditsinyi [Intern.Conf. Perspective directions of laser medicine]. Moscow-Odessa; 1992; p. 74-6. (in Russian)

6. Petukhov MI, Stranadko EPh, Andreeva KP, Kolobanov AC. Study of the light toxicity of Photohem. In: Mezhdunar. konf. Perspektivnyie napravleniya lazernoy meditsinyi [Intern. Conf. Perspective directions of laser medicine]. Moscow-Odessa; 1992; p. 428-31. (in Russian)

7. Petukhov MI, Skobelkin OK, Stranadko EPh, et al. Experimental study of specific properties of Photohem. Lazeryi $\mathrm{v}$ meditsinskoy praktike [Lasers in medical practice]. Moscow; 1992; p. 274-6. (in Russian)

8. Klebanov GI, Stranadko EPh, Teselkin YO, et al. Interaction of photosensitizers with membranes of liposomes and of erythrocytes. Photochemotherapy: photodynamic therapy and other modalities II, Stanley B. Brown, Benjamin Ehrenberg, Johan Moan, Editors, Proc. SPIE 2924, 1996; p. 205-11.

9. Skobelkin OK, Barabash RD, Andreeva CP, et al. The comparative light toxicity of porphirin photosensitizers. In: Int. Conf. on PDT, Sofia. 1989; p. 65.

10. Skobelkin OK, Stranadko EPh, Mironov APh, Kolobanov AC, et al. Progress of clinical application of fhotodynamic therapy of malignant tumors. In: Mezhdunar. konf. Perspektivnyie napravleniya lazernoy meditsinyi [Intern. Conf. Perspective directions of laser medicine]. Moscow-Odessa; 1992; p. 3-7. (in Russian)

11. Sokolov VV, Stranadko EPh, Zharkova NN, et al. Photodynamic therapy of malignant tumors of the main localizations with drugs Photohem and Photosens (the results of 3-year observations). Voprosyi onkologii [Questions of Oncology]. 1995;41(2):134-8. (in Russian)

12. Stranadko EPh, Skobelkin OK, Vorozhtsov GN, Mironov APh, et al. Five years experience of clinical application of photodynamic therapy. Ros. onkol. zhurnal [Russian biotherapeutic magazine]. 1998;4:13-8. (in Russian)
13. Stranadko EPh, Skobelkin OK, Mironov AF. Photodynamic therapy of cancer by photogem. Photodynamic therapy of cancer, Giulio Jori, Johan Moan, Willem Star, Editors, Proc. SPIE 2078; 1994; p. 499-501.

14. Stranadko EPh, Skobelkin OK, Vorozhtzov GN, et al. Four-year clinical experience in photodynamic therapy. Photochemotherapy: Photodynamic Therapy and Other Modalities II, Stanley B. Brown, Benjamin Ehrenberg, Johan Moan, editors, Proc. SPIE. 1996; Vol. 2924; p. 298-304.

15. Stranadko EPh. Lazernaya i magnitnaya terapiya v eksperimentalnyih i klinicheskih issledovaniyah [Laser and magnetic therapy in experimental and clinical studies]. Obninsk, 1993. Chast I, The first experience of photodynamic therapy of cancer in Russia; p. 69-72. (in Russian)

16. Stranadko EPh, Skobelkin OK, Litvin GD, et al. Analysis of the immediate results of photodynamic therapy of malignant tumors. In: Mezhdunar. konf. Novyie dostizheniya lazernoy meditsinyi [Intern. Conf. New achievements in laser medicine]. M.-SPb.; 1993; p. 218-20. (in Russian)

17. Stranadko EPh, Astrakhankina TA. Photodynamic therapy of breast cancer. In: Mezhdunar. konf. Novyie dostizheniya lazernoy meditsinyi [Intern. Conf. New achievements in laser medicine]. M.-SPb.; 1993; p. 221-3. (in Russian)

18. Stranadko EPh. .Experimental and clinical method of laser photodynamic therapy of malignant tumors with using of first and second generation domestic photosensitizers. Lazer-market [Laser market]. 1994;11-12:20-6. (in Russian)

19. Stranadko EPh, Astrakhankina TA. Photodynamic therapy of malignant tumors of the skin. Fizicheskaya meditsina [Physical medicine]. 1994;4(1-2):80-1. (in Russian)

20. Sobolev AS, Stranadko EPh. Photodynamic therapy in Russia: clinical and fundamental aspects. Int. Photodynamics. 1997;1(6):2-3.

21. Stranadko EPh, Skobelkin OK, Litwin GD, Astrakhankina TA. Clinical photodynamic therapy of malignant neoplasms. Photodynamic therapy of cancer II, Daniel Brault, Giulio Jori, Johan Moan, Benjamin Ehrenberg, Editors, Proc. SPIE 2325, 1995; p. 240-46.

22. Stranadko EPh, Skobelkin OK. Our experience of PDT of cancer with two russian produced photosensitizers. Optical Methods for Tumor Treatment and Detection: Mechanisms and Techniques in Photodynamic Therapy IV, Thomas J. Dougherty, Editor, Proc. SPIE, 1995; Vol. 2392, p. 93-105.

23. Stranadko EPh., Skobelkin OK, Litwin GD, Astrakhankina TA. Photodynamic therapy of human malignant tumors: a comparative stady between photogem and tetrasulfonated aluminium phthalocyanine. Photochemotherapy: photodynamic therapy and other modalities, Benjamin Ehrenberg, Giulio Jori, Johan Moan, Editors, Proc. SPIE 2625, 1995; p. 440-8.

24. Stranadko EPh, Sloeva AI, Ryabov MV. Photodynamic therapy of malignant tumors in otorhinolaryngology. Yubileynyiy sbornik Saratovskogo gos. med. universiteta "Problemyi fizicheskoy biomeditsinyi", posvyaschennyiy 100-letiyu kafedryi patologicheskoy fiziologii im. A.A. Bogomoltsa [The anniversary collection of the Saratov State Medical University "Problems of physical Biomedicine", dedicated to the 100th anniversary of the Department of pathological physiology named after A.A. Bogomoltsa]. Saratov; 2011; p. 116-31. (in Russian) 
25. Stranadko EPh, Armichev AV, Geynits AV. Sources of light for photodynamic therapy. Lazernaya meditsina [Laser medicine]. 2011;15(3):63-9. (in Russian)

26. Stranadko EPh, Titova VA, Petrovskiy VYu. Photodynamic therapy: a multimodal programme for the treatment of various localizations cancer. Lazernaya meditsina [Laser medicine] . 2012;16(3):4-7. (in Russian)

27. Chissov VI, Skobelkin OK, Mironov APh, Stranadko EPh, et al. Photodynamic therapy and fluorescent diagnostics of malignant tumors with Photohem. Hirurgiya [Surgery]. 1994;12:3-6. (in Russian)

28. Betz CS, Raushning W, Stranadko EPh, et al. Optimization of treatment parameters for Foscan-PDT of basal cell carcinomas. Lasers Surg Med. 2008;40:300-11.

29. Arsenyev AI, Gelfond ML, Klimenko VN. Intraoperative FDT in the combined treatment of primary and secondary damages of a pleura. Ros. bioter. zhurnal [Russian biotherapeutic magazine]. 2008;7(4):12-5. (in Russian)

30. Vasiliev NE, Ogirenko PA. Antimicrobial photodynamic therapy. Lazernaya meditsina [Laser medicine]. 2002;6(3):32-8. (in Russian)

31. Volgin VN, Stranadko EPh, Sokolova TV, Lamotkin IA, Ryabov MV. Optimization of the modes of photodynamic therapy of basal cell carcinoma of skin with Photosens. Lazernaya meditsina [Laser medicine]. 2007;11(1): 50-4. (in Russian)

32. Volgin VN, Stranadko EPh, Sadovskaya MV, Ryabov M.V. Expirience of application of photodynamic therapy of basal cell skin carcinoma of different locations with the photosensitizer FOTODITAZIN. Ros. bioter. zhurnal [Russian biother. magazine]. 2009;2:31-2. (in Russian)

33. Gelfond M, Arseniev A, Gafton G, et al. Radical and palliative PDT programs in combined treatment of malignant neoplasms. Proceedings of the III International Symposium "Topical problems of biophotonics". St.-Petersburg-Nizhny Novgorod, Russia. 2011; p. 323.

34. Lukyanets EA. New photosensitizers for photodynamic therapy. Ros. himich. zhurnal [Russian biotherapeutic magazine]. 1998;.HLII(5):9-16. (in Russian)

35. Stranadko EPh, Ivanov AV. Modern state of a problem photodynamic therapy of cancer and non-neoplastic diseases. Biofizika [Biophysics]. 2004;49(2):380-3. (in Russian)

36. Stranadko EPh, Skobelkin OK, Markichev NA, Ryabov MV.Photodynamic therapy of cancer (five years boundary). Lazernaya meditsina [Lazer medicine]. 1997;1(1):13-7. (in Russian)

37. Ponomarev GV, Reshetnikov AV, Ivanov AV, Stranadko EPh. Assessment of the biological activity of a new photosensitizer for clinical use of complex chlorin E6 (Fotoditazin). In: III Vserossiyskiy simpozium. Fotodinamicheskaya terapiya [The III All-Russian Symposium. Photodynamic therapy]. Moscow; 1999; p. 133-141. (in Russian)

38. Stranadko EPh, Volgin VN, Lamotkin IA, et al. Photodynamic therapy of basal cell skin carcinoma with the photosensitizer Fotoditazin. Ros. bioter. zhurnal [Rus. biotherapeutic magazine]. 2008;7(4):7-11. (in Russian)

39. Stranadko EPh, Ponomarev GV, Meshkov VM, et al. The first experience of photodithazine clinical application for photodynamic therapy of malignant tumors. Optical methods for tumor treatment and detection: mechanisms and techniques in photodynamic therapy IX,
Thomas J. Dougherty, Editor, Proc. SPIE 3909, 2000; p. 138-44.

40. Stranadko EPh, Purtskhvanidze VA, Radaev AA. Photodynamic therapy for skin cancer with chlorine derivatives under the outpaitient conditions. Photodiag. Photodyn. Ther. 2008;5(1):24.

41. Volgin VN, Stranadko EPh. Study of the pharmacokinetics of Fotoditazin basal cell skin carcinoma . Lazernaya meditsina [Laser medicine]. 2011;15(1)33-7. (in Russian)

42. Geynits AV, Stranadko EPh. Possibilities of photodynamic therapy with Fotoditazin in Oncology. Ros. bioter. zhurnal [Rus. biother. magazine]. 2009;2:31-2. (in Russian)

43. Stranadko EPh, Titova VA, Riabov MV, Petrovsky VYu. Photodynamic therapy of squamous-cellular cancer of head and neck. Photodiag. Photodyn. Ther. 2008;5(1):18.

44. Stranadko EPh, Titova VA, Riabov MV, Petrovsky VYu. Photodynamic therapy as an optimal technique for treating lower lip cancer. Photodiag Photodyn Ther. 2010;7(1):18.

45. Stranadko EPh. Photodynamic therapy of the most aggressive forms of malignant neoplasms. Proceedings of the III International Symposium. Topical problems of biophotonics. St.Petersburg-Nizhny Novgorod, Russia; 2011; p. 336-338.

46. Stranadko EPh, Tolstykh PI, Teplyashin AS, Koraboev UM. Perspectivs of application of photodynamic therapy for treatment of purulent wounds. Problemyi neotlozhnoy hirurgii [Problem of emergency surgery]. 1998;4:108-9. (in Russian)

47. Stranadko EPh, Koraboev UM, Tolstykh MP. Photodynamic therapy of purulent diseases of soft tissues. Hirurgiya [Surgery]. 2000;9:67-70. (in Russian)

48. Stranadko EPh, Tolstykh PI, Urinova Ya, et al. Photodynamic therapy of purulent-inflammatory diseases of soft tissues at patients of elderly and senile age. Klinich. gerontol. [Clin. gerontol.]. 2000;6(5-6):43-5. (in Russian)

49. Stranadko EPh, Ivannikov SV, Zharova TA, Shesternya NA. Arthroscopic photodynamic therapy of pigment-villena gonarthronieningitis. Lazernaya meditsina [Laser medicine]. 2013;17(3):57-60. (in Russian)

50. Shin PhE, Tolstykh PI, Stranadko EPh, et al. Photodynamic therapy of experimental burn wounds. Lazernaya meditsina [Laser medicine]. 2009;13(3):55-60. (in Russian)

51. Fyodorov SN, Kopaeva VG, Andreev YV, Stranadko EPh, et al. First experience of application of photodynamic therapy in keratoplasty. Laser in Ophthalmology IV. R. Dirngruber, A.F. Fercher, Ph. Sourdille, Editors, Proc. SPIE 2930, 1996; p. 63-5.

52. Fyodorov SN, Kopaeva VG, Andreev YuV, Stranadko EPh, et al. Photochemical destraction of the newly formed vessels at neovascularization of corneal transplant. Ophthalmoscope. 1996(7):46-7.

53. Kopaeva VG, Andreev YV, Stranadko EPh, Ponomarev GV. Photodestruction of neovascular vessels in neovascularization of corneal transplant. In: The XI-th Congress of International Society for Laser Surgery and Medicine. Buenos Aires; 1995; p. 129-30.

54. Stranadko EPh, Tolstykh PI, Kuleshov IYu. Antibacterial photodynamic therapy for treating non-healing purulent wounds and trophic ulcers. Photodiag. Photodyn. Ther. 2010;7(1): 37.

55. Stranadko EPh. Photodynamic therapy of malignant tumors and non-neoplastic diseases. In: 2-y Vserossiyskiy simpozium. Fotodinamichekaya terapiya zlokachestven- 
nyih novoobrazovaniy [The 2nd All-Russian Symposium. Photodynamic therapy of malignant tumors]. M.; 1997; p. 20-3. (in Russian)

56. Stranadko EPh, Garbuzov MI, Markichev NA, Ryabov MV. Photodynamic therapy of recurrent and residual tumors of oropharyngeal area in an outpatient setting. In: 2-y Vserossiyskiy simpozium. Fotodinamichekaya terapiya zlokachestvennyih novoobrazovaniy [The 2nd All-Russian Symposium. Photodynamic therapy of malignant tumors]. M.; 1997; p. 40-6. (in Russian)

57. Stranadko EPh, Ryabov MV, Markichev NA, Volkova NN. The results of the first stages of clinical use of photodynamic therapy for the treatment of malignant neoplasms. In: III Vserossiyskiy simpozium. Fotodinamicheskaya terapiya [The III All-Russian Symposium. Photodynamic therapy]. M.; 1999; p. 72-82. (in Russian)

58. Stranadko EPh, Ryabov MV, Furletova NM, et al. The study of antibacterial activity of photodynamic therapy with a new photosensitizer of chlorin range in the experiment in vitro. Lazernaya meditsina [Laser medicine]. 2002;6(1):44-7. (in Russian)

59. Chissova VI, Starinskogo VV, Petrovoy GV, editors. Zlokachestvennyie novoobrazovaniya v Rossii v 2007 godu (zabolevaemost i smertnost) [Malignant tumors in Russia in 2007 (morbidity and mortality)]. Moscow; 2009. 242 p. (in Russian)

60. Chissova VI, Starinskogo VV, Petrovoy GV, editors. Zlokachestvennyie novoobrazovaniya v Rossii v 2011 godu (zabolevaemost i smertnost) [Malignant tumors in Russia in 2011 (morbidity and mortality)]. Moscow; 2013. 289 p. (in Russian)

61. Stranadko EPh, Vasilenko YuV, Lobakov AI, et al. Possibilities of palliative photodynamic therapy in endoscopic practice. Annalyi hirurgii [Annals of surgery]. 2003;2:20-4. (in Russian)

62. Stranadko EPh, Lobakov AI, Vasilenko YuV, Ryabov MV, Mokin AV. Palliative endoscopic photodynamic therapy. Fotobiol. ta Fotomed [Photobiol. and Photomed.]. 2007;1-2:38-42. (in Russian)

63. Stranadko EPh, Lobakov AI, Morohotov VA, Ibragimov TM. Photodynamic therapy of the large duodenal papilla cancer, gall bladder and common bile duct. Ros. bioter. zhurnal [Rus. biother. magazine]. 2009(2):42-3. (in Russian)

64. Stranadko EPh, Mazurin VS, Shabarov VL, Mayorov GA. Treatment of patients with cancer of a gullet by the method of endoscopic photodynamic therapy. Lazer. med. [Laser med]. 2011;15(2):72-3. (in Russian)
65. Stranadko EPh, Mazurin VS, Shabarov VL. Photodynamic therapy in esophageal cancer. Photodiag. Photodyn. Ther. 2010;7(1):7.

66. Stranadko EPh, Meshkov VM, Vasilenko YuV, et al. Photodynamic therapy of the vater papilla cancer. Lazer. med. [Laser med.]. 2002;6(1):9-13. (in Russian)

67. Stranadko EPh, Lobakov AI, Riabov MV, Ibragimov TM. Photodynamic therapy for papilla of Vater cancer and common bile duct cancer. Photodiag. Photodyn. Ther. 2008;5(1):88.

68. Petrovskiy VYu, Titov VA, Stranadko EPh, Ryabov MV. Photodynamic therapy in multicomponent programms of treatment of oropharyngeal cancer. Sibirskiy onkol. zhurnal [Siberian oncol. mag.]. 2006;1:84-5. (in Russian)

69. Stranadko EPh, Ryabov MV, Titova VA, Petrovskiy VYu. Photodynamic therapy as the main component of the combined and complex treatment of squamous cell cancer of the head and neck. In: XI mezhdunar. konf. Novyie meditsinskie tehnologii i kvantovaya meditsina [The XI Intern. Conf. New medical technologies and quantum medicine]. Moscow; 2005; p. 105. (in Russian)

70. Stranadko EPh, Titov VA, Ryabov MV, Petrovskiy VYu. Photodynamic therapy of cancer of the lower lip: an experience of use in combination with the traditional method of prevention of metastasis. Lazer. med. [Laser med.]. 2006;10(3):41-7. (in Russian)

71. Stranadko EPh, Titov VA, Ryabov MV, Petrovskiy VYu. Photodynamic therapy in programs multicomponent organ-preserving treatment of squamous cell cancer of the head and neck. In: XXX mezhdunar. nauch.-prakt. konfer. Primenenie lazerov v meditsine i biologii [The XXX Internat. Scient.-Pract. Conf. Application of lasers in medicine and biology]. Yalta; 2008; p. 58-60. (in Russian)

72. Stranadko EPh, Titov VA, Ryabov MV, Petrovskiy VYu. The Role of photodynamic therapy in combined treatment of squamous cell cancer of the head and neck. In: III Evraziyskiy kongress po med. fizike i inzhenerii. Meditsinskaya fizika - 2010 [The III Eurasian Congress on medical physics and engineering. Medical physics - 2010]. Moscow; 2010; 4; p. 269-71. (in Russian)

73. Titova VA, Kharchenko NV, Stranadko EPh, et al. Photodynamic therapy in multimodality treatment of locally advanced and recurrent oral cancer.Photodiag. Photodyn. Ther. 2008;5(1):20.

74. Betz ChS, Raushning W, Stranadko EPh, Ryabov MV, Volgin VN, Albrecht V, Nifantiev NE, et al. Long-Term Outcomes Following Foscan-PDT of basal cell carcinomas. Lasers in surgery and medicine. 2012;44:533-40. 